\title{
False claims about so called vitamin B 17
}

\author{
Ginter $E^{1}$, Simko $V^{2}$ \\ Institute of Preventive and Clinical Medicine, Bratislava, Slovakia. ginter.emil@mail.t-com.sk
}

Bratisl Lek Listy published in 2010 a number of remarkable papers related to malignancy but, for a good reason, nothing on the vitamin B $17(1,2)$. Various other Slovak and foreign periodicals advertised recommendations for a product derived from almonds designed ,vitamin B 17“. Sequential designation „17“ is as problematic as the claim for this compound to be biologically effective, allegedly for various types of cancer.

Mass produced advertisements under the attractive title WORLD WITHOUT CANCER (Griffin) have promoted the misleading idea of cancer being a variant of deficiency-like scurvy or pellagra - aggravated by the lack of an „essential“ food compound, vitamin B17 - also called laetrile. Carried to extreme, such ,hypothesis“ would mean that most global mortality of cancer is from deficiency of vitamin B17, i.e. an inadequate regular consumption of almonds. Consequently, despite serious criticism in science circles, laetrile has been widely used among cancer patients (e.g. by many US citizens in Mexico) in the hope that it might stop or slow the process of malignant disease.

This compound is one of cyanogenic glucosides. Its history is long. It was isolated from bitter almonds in 1830. In 1949, the amygdalin extract was granted an US patent. The cyanide in amygdalin was supposed to kill cancer cells. Scientific criticism mounted and in 1953 California condemned its use and laetrile was declared illegal.

Given the lack of its biological effectiveness, laetrile has not been approved by the U.S. Food and Drug Administration. The U.S. National Institutes of Health evaluated the evidence separately and concluded that clinical trials of amgydalin showed little or no effect against cancer. In 1982, a trial of 178 patients found that the tumor size had increased in all patients and the authors reported that the hazards of amygdalin therapy were evidenced in several patients by symptoms of cyanide toxicity or by blood cyanide levels approaching the lethal range (3). The authors concluded "Patients exposed to this agent should be instructed about the danger of cyanide poisoning, and their blood cyanide levels should be carefully monitored. Amygdalin (laetrile) is a toxic drug that is not effective as a cancer treatment".

Numerous reports in the past denied the effectiveness of laetrile and warned about the risk of its use. Figure 1 indicates that the molecular structure of laetrile resembles amygdaline. It includes cyanide ( $\mathrm{CN}$ in the circle on Fig.1) which is metabolized in the organism as a highly toxic compound. As long ago as in 1977, there was a report of a tragic outcome in an 11 months old baby who incidentally swallowed five tablets $(2.5 \mathrm{~g})$ of laetrile. Subsequently the child developed a cyanide coma and died in three days. Tragic consequences of laetrile overdose are numerous (4-6).

The claim that laetrile has beneficial effects for cancer has not been supported by sound clinical data (7-9). Laetrile neither caused shrinkage

Institute of Preventive and Clinical Medicine, Bratislava, Slovakia (emeritus), and ${ }^{2}$ State University of New York, Downstate MedicalCenteratBrooklyn, USA

Address for correspondence: E. Ginter, RND, DrSc, Racianska 17, 83102 Bratislava.

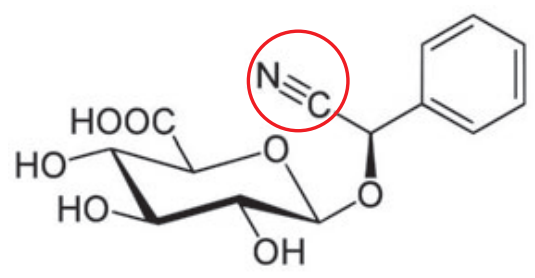

Fig. 1. Molecular structure of laetrile. The circle indicates the presence of the dangerous $\mathrm{CN}$ component.

of tumours, nor alleviated cancer symptoms. Laetrile has caused serious, life-threatening toxicity. In light of the lack of efficacy of laetrile and its demonstrated ability to cause harm, laetrile should not be used to treat cancer. According to Greenberg (9), the writings of laetrile proponents are filled with erroneous and absurd statements. The propaganda for the doctrine of "freedom of choice in cancer treatment" deludes many individuals with treatable cancer and they may reject proven methods of treatment".

The label "unproven" is inappropriately defensive for laetrile therapy; it is time to vehemently assert that laetrile cancer therapy has been "disproven." $(9,10)$. On the basis of an extensive data search we propose that this ,,wondrous vitamin B 17“ is banned by regulatory authorities in the Slovak Republic.

\section{References}

1. Valaskova Z, El-Hassoun O, Galfiova P et al. Perspective and complexity of experimental cancer study. The secrets of tumorigenesis. Bratisl Lek Listy 2010; 111 (1): 9-12.

2. Kemik O, Sumer A, Sarbay Kumik A et al. Circulating levels of VEGF family and their receptors in hepatocellular carcinoma. Bratisl Lek Listy 2010; 111 (9): 485-488.

3. Moertel CG, Fleming TR, Rubin J. A clinical trial of amygdalin (Laetrile) in the treatment of human cancer. New Engl J Med 1982; 306 (4): 201-206.

4. Herbert V. Laetrile: the cult of cyanide. Promoting poison for profit. Am J clin Nutr 1979; 32: 1121-1158.

5. O'Brien B, Quigg C, Leong T. Severe cyanide toxicity from 'vitamin supplements. Eur J Emerg Med 2005; 12 (5): 257-258.

6. Hall AH, Linden CH, Kulig KW, Rumack BH. Cyanide poisoning from laetrile ingestion: role of nitrite therapy. Pediatrics 1986; 78 (2): 269-272.

7. Milazzo S, Lejeune S, Ernst E. Laetrile for cancer: a systematic review of the clinical evidence. Support Care Cancer 2007; 15 (6): 583-595.

8. Anonymous. Unproven methods of cancer management. Laetrile. CA Cancer J Clin 1991; 41 (3): 187-192.

9. Greenberg DM. The case against laetrile: the fraudulent cancer remedy. Cancer 1980; 45 (4): 799-807.

10. Vickers AJ, Kuo J, Cassileth BR. Unconventional Anticancer Agents: A Systematic Review of Clinical Trials. J Clin Oncol 2006; 24 (1): 136-140.

Received January 19, 2011. Accepted January 20, 2013. 